\title{
Dissociation by steroids of eosinophilic inflammation from airway hyperresponsiveness in murine airways Mark A Birrell ${ }^{1}$, Cliff H Battram², Paul Woodman², Kerryn McCluskie ${ }^{1}$ and Maria G Belvisi*1
}

Address: ${ }^{1}$ Imperial College School of Medicine, London, UK, ${ }^{2}$ Novartis, Horsham, East Sussex, UK and ${ }^{3}$ Bayer Plc., Slough, Berks., UK

Email: Maria G Belvisi* - m.belvisi@ic.ac.uk

${ }^{*}$ Corresponding author

Published: 2 I March 2003

Respir Res 2003, 4:3

This article is available from: http://www.respiratory-research/content/4/1/3

(C) $2003 \mathrm{Kim}$ et al; licensee BioMed Central Ltd. This article is published in Open Access: verbatim copying and redistribution of this article are permitted in all media for any non-commercial purpose, provided this notice is preserved along with the article's original URL

\begin{abstract}
Background: The link between eosinophils and the development of airway hyperresponsiveness (AHR) in asthma is still controversial. This question was assessed in a murine model of asthma in which we performed a dose ranging study to establish whether the dose of steroid needed to inhibit the eosinophil infiltration correlated with that needed to block AHR.
\end{abstract}

Methods: The sensitised BALB/c mice were dosed with vehicle or dexamethasone $(0.01-3 \mathrm{mg} / \mathrm{kg})$ 2 hours before and 6 hours after each challenge (once daily for 6 days) and 2 hours before AHR determination by whole-body plethysmography. At 30 minutes after the AHR to aerosolised methacholine the mice were lavaged and differential white cell counts were determined. Challenging with antigen caused a significant increase in eosinophils in the bronchoalveolar lavage (BAL) fluid and lung tissue, and increased AHR.

Results: Dexamethasone reduced $B A L$ and lung tissue eosinophilia $\left(E_{50}\right.$ values of 0.06 and 0.08 $\mathrm{mg} / \mathrm{kg}$, respectively), whereas a higher dose was needed to block $A H R\left(E_{50}\right.$ of $0.32 \mathrm{mg} / \mathrm{kg}$ at $3 \mathrm{mg} /$ $\mathrm{ml}$ methacholine. Dissociation was observed between the dose of steroid needed to affect AHR in comparison with eosinophilia and suggests that AHR is not a direct consequence of eosinophilia.

Conclusion: This novel pharmacological approach has revealed a clear dissociation between eosinophilia and AHR by using steroids that are the mainstay of asthma therapy. These data suggest that eosinophilia is not associated with AHR and questions the rationale that many pharmaceutical companies are adopting in developing low-molecular-mass compounds that target eosinophil activation/recruitment for the treatment of asthma.

\section{Introduction}

Airway inflammation and hyperresponsiveness (AHR) are recognised as major characteristics of bronchial asthma; however, their relationship is still poorly understood. Exposure to allergen causes an increase in airway responsive- ness that is associated with an influx of inflammatory cells, particularly eosinophils, into the airways in allergic humans [1] and sensitised mice [2], which suggests a causal relationship between airway inflammation and AHR $[3,4]$. However, there is also much published literature 
suggesting that there is no relationship between allergic airway inflammation and AHR.

In this study we wished to determine whether there was a dissociation between the effective dose of a steroid, dexamethasone, needed to affect antigen-induced AHR in comparison with that needed to affect airway inflammation in the mouse. We have previously described a murine model of asthma that includes non-specific AHR and associated eosinophilia in the airways [5]. In the present study we followed the same sensitising and challenging protocol but decided to determine AHR in conscious, spontaneously breathing, unrestrained mice by wholebody plethysmography [6-9]. Airway responsiveness was expressed as enhanced pause $\left(P_{\text {enh }}\right)$, a calculated value, which is an indirect measurement that is correlated with measurement of airway resistance, impedance and intrapleural pressure in the same animal [6]. This method was chosen instead of our previously used invasive method because it might offer several potential advantages: it is technically less demanding, it allows repeated measurements over a long period and it avoids the use of anaesthetic and mechanical ventilation. However, one possible disadvantage is that one cannot rule out a contribution by the nose and upper respiratory tract to the parameters measured. This method of antigen-induced airway inflammation and AHR is very similar to that of Dohi et al. [9] in which they report a strong correlation between $P_{\text {enh }}$ and eosinophil number in bronchoalveolar lavage (BAL) fluid.

\section{Materials and methods Animals}

Male Balb/C mice (14-16 g, 5 weeks old), were obtained from Harlan (Bicester, Oxon., UK), and housed for 1 week before experiments were initiated. Food and water were supplied ad libitum. Experiments were performed in accordance with the UK Home Office guidelines for animal welfare based on the Animals (Scientific Procedures) Act 1986.

\section{Study design}

The aim of this study was to determine whether there was dissociation between the effective dose of a steroid needed to affect antigen-induced airway inflammation and AHR.

\section{Sensitisation and antigen challenge protocol}

Mice were immunised on days 0 and 14 by intraperitoneal (i.p.) injection of $10 \mu \mathrm{g}$ of ovalbumin (Grade V; SigmaAldrich, Poole, Dorset, UK), in $0.2 \mathrm{ml}$ of saline (Fresenius Kabi, Warrington, Cheshire, UK) with 20 mg of aluminium hydroxide (Merck, Lutterworth, Leicester, UK). From day 21 the animals were challenged with aerosolised ovalbumin (5\% in saline) or vehicle (saline) for 20 minutes per day on six consecutive days. Aerosol generation was achieved by use of an air-driven nebuliser (System 22; Medic-aid, Pagham, West Sussex, UK).

\section{Administration of dexamethasone}

Vehicle (1\% carboxymethylcellulose [Merck, Lutterworth, Leics., UK] in distilled water) or dexamethasone (SigmaAldrich) was administered twice daily by the oral route in a dose volume of $10 \mathrm{ml} / \mathrm{kg}(0.01-3 \mathrm{mg} / \mathrm{kg})$, the day before the first ovalbumin challenge, 2 hours before and 6 hours after subsequent challenges and on the morning of the AHR determination.

\section{Airways mechanics measurements in nonrestrained, conscious mice}

Twenty-four hours after the last ovalbumin challenge, mice were placed in a whole-body plethysmograph to facilitate the measurement of lung function as described by Tsuyuki et al. [7]. Bronchoconstriction to aerosolised methacholine (MCh) (3 or $10 \mathrm{mg} / \mathrm{ml}$ for 60 seconds with 5 minute intervals) (Sigma-Aldrich) was determined.

\section{Inflammatory cells in the lung}

One hour after the last MCh challenge the mice were killed by anaesthetic overdose (pentobarbitone sodium, 200 mg/kg; Rhone Merieux, Harlow, Essex, UK). BAL was performed with three $0.3 \mathrm{ml}$ aliquots of Roswell Park Memorial Institute medium (RPMI 1640; Life Technologies, Paisley, Renfrewshire, UK). The lungs were removed, and were then cleaned and finely chopped after blood had been perfused out. The chopped tissue was then digested enzymatically to obtain inflammatory cells, as described by Underwood et al. [10]. Total counts of cells recovered in the BAL fluid and tissue digest were made with an automated cell counter (Sysmex F-820; Sysmex UK, Linford Wood, Bucks., UK). Differential counts of cells (eosinophils, neutrophils, macrophages, monocytes and lymphocytes) recovered in the samples were made by light microscopy, of cytocentrifuge preparations (100 $\mu \mathrm{l}$ aliquots spun at $700 \mathrm{rpm}$ for 5 minutes at low acceleration) (Cytospin; Shandon Scientific, Runcorn, Cheshire, UK), which had been stained with Wright-Giemsa stain (Sigma-Aldrich), with a Hematek 2000 (Ames Co., Elkhart, Indiana, USA).

\section{Statistical analysis}

All values are presented as means \pm SEM per group with $n$ $=10 . \mathrm{ED}_{50}$ values stated are defined as the amount of drug required to elicit $50 \%$ of the maximum inhibition. Statistical analysis was made by analysis of variance with a correction for multiple comparisons. $P<0.05$ was considered to be statistically significant. 

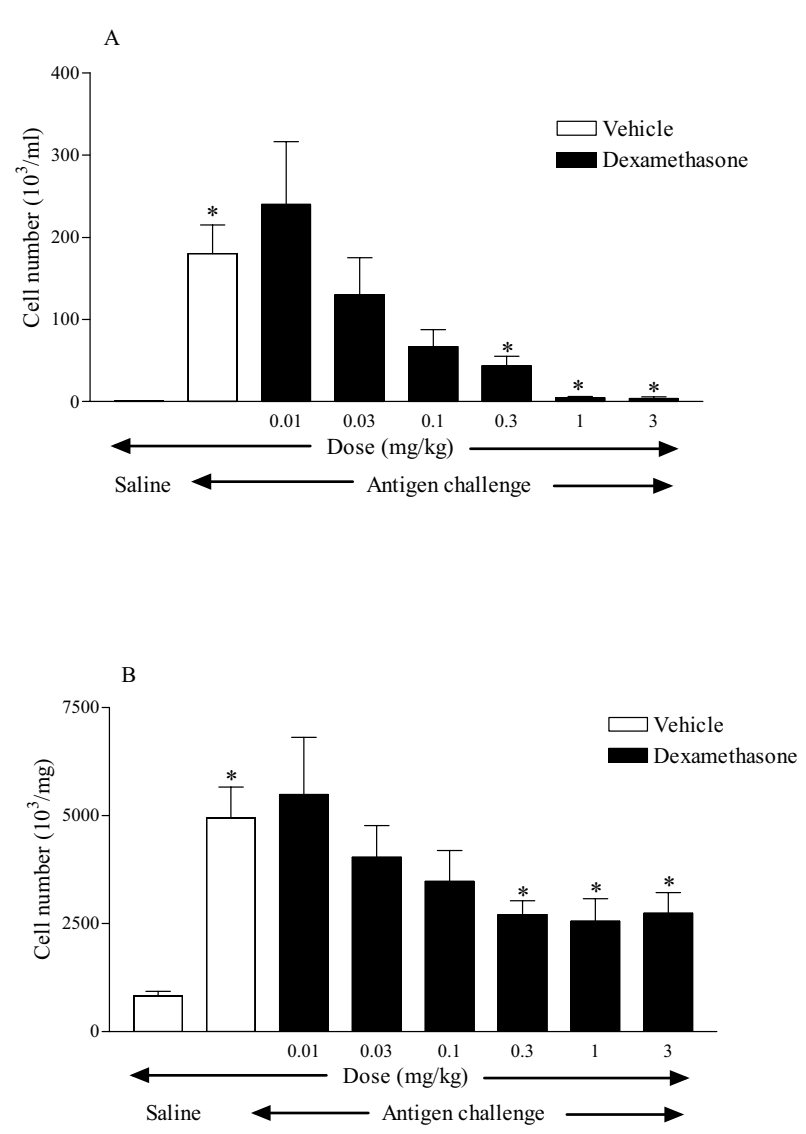

Figure I

Effect of dexamethasone treatment on BAL $(A)$ and lung tissue (B) eosinophil number 24 hours after the last antigen challenge in sensitised mice. Results represent mean \pm s.e.m. $(\mathrm{n}=10)$. $* \mathrm{P}<0.05$ compared with relevant vehicle dosed control group.

\section{Results}

\section{Inflammatory cells in the lung}

Antigen challenge caused a significant increase in eosinophils recovered in the BAL fluid and lung tissue. Dexamethasone evoked a significant dose-related inhibition of antigen-induced eosinophilia in the BAL fluid and lung tissue, with $\mathrm{ED}_{50}$ values of 0.08 and $0.06 \mathrm{mg} / \mathrm{kg}$, respectively (Fig. 1 and Table 1). The higher doses of dexamethasone almost completely abolished BAL eosinophilia but inhibited tissue eosinophilia only by about $50 \%$.

Antigen challenge also significantly increased neutrophil, monocyte and lymphocyte numbers in BAL fluids, and neutrophil, macrophage, monocyte and lymphocyte numbers in lung tissue (Table 2). This increase in numbers of inflammatory cells was significantly inhibited by dexamethasone treatment, although the effect on tissue neutrophilia did not reach statistical significance (Tables 1 and 2).

\section{Airway responsiveness}

There was no change in basal $P_{\text {enh }}$ after multiple antigen challenge when compared with saline controls and there was no effect of dexamethasone treatment on basal $P_{\text {enh }}$ at the doses tested. Antigen challenge significantly increased airway responsiveness to inhaled MCh compared with saline controls. Dexamethasone treatment significantly inhibited AHR (Fig. 2A depicts peak changes after $3 \mathrm{mg} / \mathrm{ml}$ $\mathrm{MCh}$ ). Figure 2B represents an effective dose of dexamethasone $(1 \mathrm{mg} / \mathrm{kg})$ on all of the concentrations of MCh including positive and negative controls. A higher dose of dexamethasone was needed to block AHR than eosinophilia when $\mathrm{ED}_{50}$ values are compared (Table 1).

\section{Discussion}

In this study we have shown for the first time that there is dissociation between the dose of steroid needed to affect antigen-induced BAL and lung tissue eosinophilia and that needed to affect AHR. The $\mathrm{ED}_{50}$ dose of dexamethasone required to inhibit AHR is higher than that needed to inhibit eosinophilia. It is possible that eosinophilia has to be completely inhibited to have an effect on AHR; indeed, at $1 \mathrm{mg} / \mathrm{kg}$ dexamethasone, eosinophil infiltration into the BAL fluid following challenge is almost completely blocked and at the same dose AHR is also completely reversed. Lung tissue eosinophilia, however, is only inhibited by about $50 \%$ at $1 \mathrm{mg} / \mathrm{kg}$ dexamethasone, which further indicates the dissociation between eosinophilia and AHR. De Bie et al. [11] showed that dexamethasone $(0.5 \mathrm{mg} / \mathrm{kg})$ inhibited both antigen-induced AHR and airway eosinophilia in the mouse; however, using similar doses we found only an effect on eosinophilia. In the study by De Bie et al. [11] they administered the steroid intraperitoneally and employed a different way of measuring AHR, which might account for the difference.

Throughout the literature there are reports of various interventions that affect both allergic AHR and eosinophilia. Antibodies against interleukin-5 (IL-5) have been shown to inhibit both AHR and eosinophilia in the mouse [1214]. Both allergic AHR and eosinophilia have been shown to be reduced in the following cases: in mice deficient in ICAM-1 (intercellular cell-adhesion molecule-1) [15] by treatment with an anti-B7-2 (CD86) monoclonal antibody $[7,16]$ and with an anti-CTLA4-IgG [17]; in V $\beta 8^{+}$-deficient mice and $\mathrm{BALB} / \mathrm{c}$ mice treated with antibodies against $\mathrm{V} \beta 8$ [18]; in mice lacking a functioning 5-lipoxygenase enzyme [19]; in interferon- $\beta$-treated mice [20]; in IL-12 treated mice $[21,22]$; and in mice treated with an immunosuppressive agent, FK-506 [8]. 
Table I: Effect of dexamethasone treatment on inflammatory cell numbers in bronchoalveolar lavage (BAL) fluid and lung tissue after the last antigen challenge in sensitised mice

\begin{tabular}{lllllll}
\hline Parameter & Eosinophils & Neutrophils & Macrophages & Monocytes & Lymphocytes & MCh challenge $(3 \mathrm{mg} / \mathrm{ml})$ \\
\hline BAL ED $_{50}$ & 0.08 & 0.14 & - & 0.09 & 0.10 & - \\
Tissue ED & -06 & - & 0.13 & 0.13 & 0.08 & - \\
AHR peak changes, ED & - & - & - & - & 0.35 \\
AHR AUC changes, ED $E_{50}$ & - & - & - & - & - & 0.32 \\
\hline
\end{tabular}

Results are expressed as $\mathrm{ED}_{50}$ values, in $\mathrm{mg} / \mathrm{kg}$ of dexamethasone. AHR, airway hyperresponsiveness; $\mathrm{AUC}$, area under the curve; $\mathrm{MCh}$, methacholine.

Table 2: Effect of dexamethasone treatment on inflammatory cell numbers in bronchoalveolar lavage (BAL) fluid and lung tissue after the last antigen challenge in sensitised mice

\begin{tabular}{lllllllll}
\hline Cell type & Vehicle saline & Vehicle OA & Dex 0.0I OA & Dex 0.03 OA & Dex 0.1 OA & Dex 0.3 OA & Dex I OA & Dex 3 OA \\
\hline $\begin{array}{l}\text { BAL } \\
\text { eosinophils }\end{array}$ & $0.6 \pm 0.2$ & $180.3 \pm 34.6^{*}$ & $239.8 \pm 76.5$ & $129.9 \pm 45.3$ & $66.9 \pm 20.6$ & $43.6 \pm 11.5^{*}$ & $4.6 \pm 1.7^{*}$ & $3.6 \pm 2.1^{*}$ \\
$\begin{array}{l}\text { BAL } \\
\text { neutrophils }\end{array}$ & $0.7 \pm 0.3$ & $449.4 \pm 76.7^{*}$ & $617.9 \pm 196.7$ & $335.2 \pm 93.9$ & $218.8 \pm 59.5$ & $173.6 \pm 46.8$ & $38.5 \pm 11.2^{*}$ & $29.8 \pm 10.2^{*}$ \\
$\begin{array}{l}\text { BAL } \\
\text { macrophages }\end{array}$ & $104.4 \pm 16.5$ & $68.6 \pm 12.7$ & $79.9 \pm 14.2$ & $91.5 \pm 14.2$ & $57.0 \pm 11.3$ & $65.5 \pm 5.5$ & $71.7 \pm 10.5$ & $70.9 \pm 4.7$ \\
$\begin{array}{l}\text { BAL } \\
\text { monocytes }\end{array}$ & $10.2 \pm 2.0$ & $62.4 \pm 8.5^{*}$ & $68.6 \pm 19.5$ & $52.2 \pm 14.0$ & $37.7 \pm 9.2$ & $25.8 \pm 6.5$ & $6.1 \pm 1.0^{*}$ & $6.6 \pm 1.6^{*}$ \\
$\begin{array}{l}\text { BAL } \\
\text { Lymphocytes }\end{array}$ & $6.2 \pm 1.8$ & $80.4 \pm 12.9^{*}$ & $111.5 \pm 39.1$ & $62.3 \pm 18.0$ & $37.4 \pm 13.0$ & $28.2 \pm 6.7$ & $5.6 \pm 1.2^{*}$ & $6.9 \pm 1.7^{*}$ \\
$\begin{array}{l}\text { Tissue } \\
\text { eosinophils }\end{array}$ & $823 \pm 108$ & $4944 \pm 715^{*}$ & $5480 \pm 1323$ & $4033 \pm 734$ & $3479 \pm 713$ & $2703 \pm 328^{*}$ & $2557 \pm 519^{*}$ & $2739 \pm 476^{*}$ \\
$\begin{array}{l}\text { Tissue } \\
\text { neutrophils }\end{array}$ & $4948 \pm 622$ & $21869 \pm 2756^{*}$ & $22884 \pm 4686$ & $22261 \pm 5450$ & $16166 \pm 2473$ & $14520 \pm 1767$ & $15188 \pm 1750$ & $18619 \pm 1805$ \\
$\begin{array}{l}\text { Tissue } \\
\text { macrophages }\end{array}$ & $571 \pm 95$ & $4721 \pm 1277^{*}$ & $4590 \pm 1266$ & $3602 \pm 754$ & $2887 \pm 841$ & $2267 \pm 714$ & $689 \pm 239^{*}$ & $311 \pm 125^{*}$ \\
$\begin{array}{l}\text { Tissue } \\
\text { monocytes }\end{array}$ & $367 \pm 78$ & $6889 \pm 1316^{*}$ & $7946 \pm 2196$ & $5524 \pm 1524$ & $3923 \pm 993$ & $2737 \pm 1168$ & $304 \pm 69^{*}$ & $196 \pm 75^{*}$ \\
$\begin{array}{l}\text { Tissue } \\
\text { lymphocytes }\end{array}$ & $1069 \pm 98$ & $8277 \pm 1327^{*}$ & $8292 \pm 2638$ & $5912 \pm 1696$ & $3990 \pm 959$ & $3440 \pm 959$ & $707 \pm 156^{*}$ & $691 \pm 116.5^{*}$ \\
\hline
\end{tabular}

The concentration of cells in BAL fluid was $10^{3} / \mathrm{ml}$ (the volume of BAL recovered in the lavage in this experiment was $0.6 \mathrm{ml}$ from each animal) and that of tissue cells was $103 / \mathrm{mg}$ of tissue. Results are means \pm SEM $(n=10)$. Asterisks indicate a significant difference $(P<0.05)$ from the relevant vehicle-dosed control group. OA, Ovalbumin.

There are reports of interventions inhibiting allergic eosinophilia but not AHR: in humans, an IL-5-blocking monoclonal antibody [23]; in mice, antibodies against IL-5 [24-26] and IL-5 knockout animals [27]. Other interventions have been shown to have the reverse effect, inhibiting allergic AHR without affecting eosinophilia: antibodies against interferon- $\gamma$ in mice [26], antibodies against IL-16 in mice [28], IL-10-deficient mice [29] and mast-cell-deficient mice $[24,25]$; Tournoy et al. [30] showed that by lowering the allergic challenge eosinophilia was lost but AHR remained.

Treatment with dexamethasone inhibited other leukocytes measured in the lung with $\mathrm{ED}_{50}$ values comparable to those determined for eosinophilia (Table 1). This would suggest that these inflammatory cells are also not associated with AHR; indeed, neutrophil numbers in the BAL fluid and tissue were not reduced to unchallenged levels by any dose of steroid used here (Table 2), whereas AHR was completely reversed. The involvement in AHR of other leukocytes measured here cannot be completely ruled out because it might be necessary to completely inhibit their infiltration into the lung before any impact on AHR is observed. Increased levels of macrophages, monocytes and lymphocytes in the lung were only completely inhibited at $1 \mathrm{mg} / \mathrm{kg}$ of dexamethasone, which is the corresponding dose needed to block AHR.

There is therefore a wealth of literature on the association between allergic eosinophilia and AHR that is sometimes 

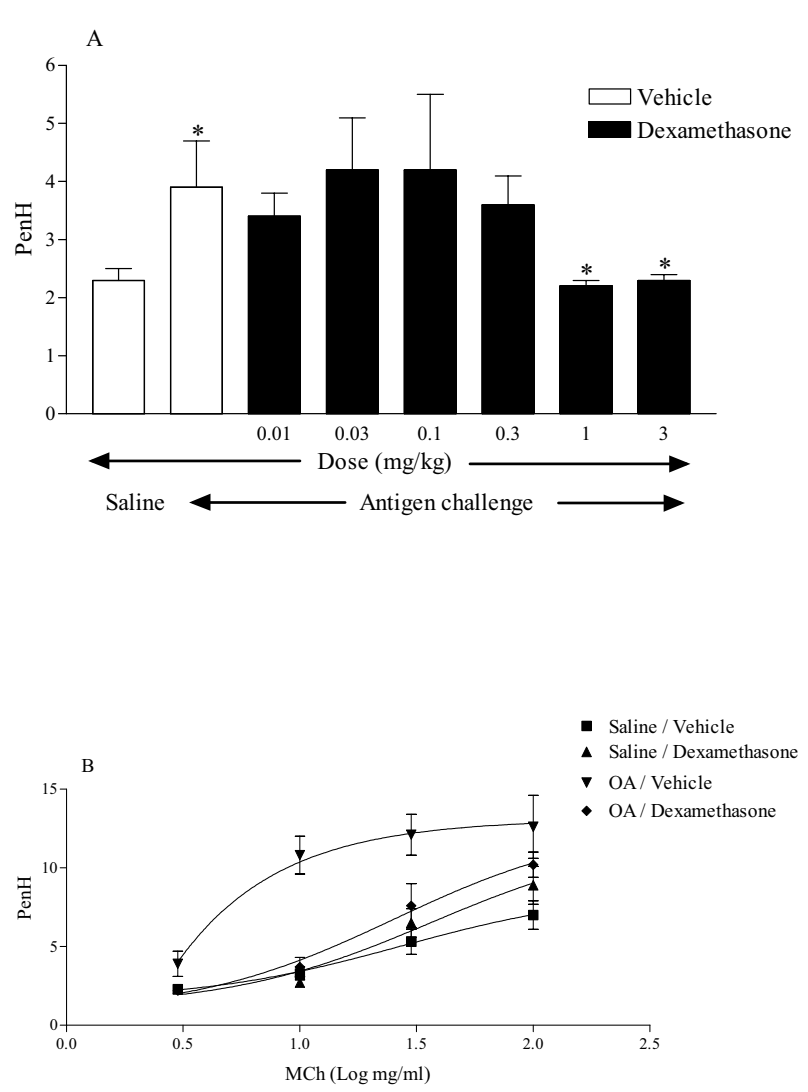

Figure 2

Effect of dexamethasone $(0.01-3 \mathrm{mg} / \mathrm{kg}$ ) on peak changes in PenH measured after aerosolised methacholine $(3 \mathrm{mg} / \mathrm{ml}$ for 60sec) 24 hours after the last antigen challenge in sensitised mice (Figure 2A). Effect of dexamethasone $(1 \mathrm{mg} / \mathrm{kg}$ ) on peak changes in PenH measured after aerosolised methacholine (3 - $100 \mathrm{mg} / \mathrm{ml}$ for $60 \mathrm{sec}) 24$ hours after the last antigen challenge in sensitised mice (Figure 2B). Results represent mean \pm s.e.m. $(n=10)$. $* P<0.05$ compared with relevant vehicle dosed control group.

confusing and contradictory. This is the first study that has addressed this question with a range of doses of corticosteroid, compounds known to block AHR and eosinophilia in all animal models of asthma and to affect inflammation and AHR in asthmatics in a clinical setting. We feel that this novel pharmacological approach has revealed a clear dissociation between eosinophilia and AHR in the same animal and this concurs with a study in humans showing no correlation between AHR and the number of inflammatory cells in sputum or bronchoalveolar lavage [31]. These data question the rationale that many pharmaceutical and biotechnology companies have adopted in embarking on drug discovery programmes that target the eosinophil activation/infiltration signalling pathways (e.g. IL-5, VLA-4 and CCR-3).

These data suggest that other factors, such as airway wall remodelling, activation state of the eosinophils, T-cell activation or autonomic dysfunction, might be more important in the development of AHR.

\section{Conclusion}

Dissociation was observed between the dose of steroid needed to affect AHR compared with that required to affect inflammation, suggesting that AHR is not a direct consequence of eosinophilia. This novel pharmacological approach has revealed a clear dissociation between eosinophilia and AHR by using steroids that are the mainstay of asthma therapy. If the eosinophil is not associated with AHR, as this result suggests, the information described here is vitally important given that many pharmaceutical companies are engaged in developing low-molecularmass compounds that target eosinophil activation/recruitment for the treatment of asthma.

\section{Abbreviations}

AHR $=$ airway hyperresponsiveness $; \mathrm{BAL}=$ bronchoalveolar lavage; IL = interleukin; i.p. = intraperitoneal; $\mathrm{MCh}=$ methacholine; $P_{\text {enh }}=$ enhanced pause.

\section{Acknowledgements}

We thank David Hele for his advice on the manuscript, and the Harefield Research Foundation and the British Heart Foundation for financial support.

\section{References}

I. Brusasco V, Crimi E, Gianiorio P, Lantero S and Rossi GA Allergeninduced increase in airway responsiveness and inflammation in mild asthma. J Appl Physiol 1990, 69:2209-22 I4

2. Wanner A, Abraham WM, Douglas JS, Drazen JM, Richerson HB and Ram JS NHLBI Workshop Summary. Models of airway hyperresponsiveness. Am Rev Respir Dis 1990, 141:253-257

3. Kirby JG, Hargreave FE, Gleich GJ and O'Byrne PM Bronchoalveolar cell profiles of asthmatic and nonasthmatic subjects. $A m$ Rev Respir Dis 1987, 136:379-383

4. Bradley BL, Azzawi M, Jacobson M, Assoufi B, Collins JV, Irani AM, Schwartz LB, Durham SR, Jeffery PK and Kay AB Eosinophils, T. lymphocytes, mast cells, neutrophils, and macrophages in bronchial biopsy specimens from atopic subjects with asthma: comparison with biopsy specimens from atopic subjects without asthma and normal control subjects and relationship to bronchial hyperresponsiveness. J Allergy Clin Immunol |99|, 88:66I-674

5. Battram C, Birrell M, Foster M, Webber SE and Belvisi MG Comparison of inhaled spasmogen as determinants of airway hyperresponsiveness in a murine model of asthma. $\mathrm{Br} J$ Pharmacol 1999, I 28:27IP

6. Hamelmann E, Schwarze J, Takeda K, Oshiba A, Larsen GL, Irvin CG and Gelfand EW Noninvasive measurement of airway responsiveness in allergic mice using barometric plethysmography. Am J Respir Crit Care Med 1997, 156:766-775

7. Tsuyuki S, Tsuyuki J, Einsle K, Kopf M and Coyle AJ Costimulation through B7-2 (CD86) is required for the induction of a lung mucosal T helper cell 2 (TH2) immune response and altered airway responsiveness. J Exp Med 1997, 185:167I-1679

8. Eum SY, Zuany-Amorim C, Lefort J, Pretolani M and Vargaftig BB Inhibition by the immunosuppressive agent FK-506 of antigen- 
induced airways eosinophilia and bronchial hyperreactivity in mice. BrJ Pharmacol 1997, 120:130-136

9. Dohi M, Tsukamoto S, Nagahori T, Shinagawa K, Saitoh K, Tanaka $Y$ Kobayashi S, Tanaka R, To $Y$ and Yamamoto $K$ Noninvasive system for evaluating the allergen-specific airway response in a murine model of asthma. Lab lnvest 1999, 79: 1559-|57|

10. Underwood SL, Raeburn D, Lawrence C, Foster M, Webber S and Karlsson JA RPR 10 a novel, airways-selective glucocorticoid: effects against antigen-induced CD4+ T lymphocyte accumulation and cytokine gene expression in the Brown Norway rat lung. $B r J$ Pharmacol $654 I$, I 22:439-446

II. De Bie |], Hessel EM, Van Al, Van Esch B, Hofman G, Nijkamp FP and Van Oosterhout AJ Effect of dexamethasone and endogenous corticosterone on airway hyperresponsiveness and eosinophilia in the mouse. Br J Pharmacol I996, I I 9: I484-I490

12. Hamelmann E, Oshiba A, Loader J, Larsen GL, Gleich G, Lee J and Gelfand EW Antiinterleukin-5 antibody prevents airway hyperresponsiveness in a murine model of airway sensitization. Am J Respir Crit Care Med 1997, 155:819-825

13. Hogan SP, Koskinen A and Foster PS Interleukin-5 and eosinophils induce airway damage and bronchial hyperreactivity during allergic airway inflammation in BALB/c mice. Immunol Cell Biol 1997, 75:284-288

14. Cieslewicz G, Tomkinson A, Adler A, Duez C, Schwarze J, Takeda K, Larson KA, Lee JJ, Irvin C and Gelfand EW The late, but not early, asthmatic response is dependent on IL-5 and correlates with eosinophil infiltration. J Clin Invest 1999, 104:30I-308

15. Wolyniec WW, De Sanctis GT, Nabozny G, Torcellini C, Haynes N, Joetham A, Gelfand EW, Drazen JM and Noonan TC Reduction of antigen-induced airway hyperreactivity and eosinophilia in ICAM-I-deficient mice. Am J Respir Cell Mol Biol I998, I 8:777-785

16. Haczku A, Takeda K, Redai I, Hamelmann E, Cieslewicz G, Joetham A, Loader J, Lee JJ, Irvin C and Gelfand EW Anti-CD86 (B7.2) treatment abolishes allergic airway hyperresponsiveness in mice. Am J Respir Crit Care Med 1999, 159:1638-1643

17. Van Oosterhout AJ, Hofstra CL, Shields R, Chan B, Van Ark I, Jardieu PM and Nijkamp FP Murine CTLA4-IgG treatment inhibits airway eosinophilia and hyperresponsiveness and attenuates IgE upregulation in a murine model of allergic asthma. $\mathrm{Am} \mathrm{J}$ Respir Cell Mol Biol 1997, 17:386-392

18. Hofstra CL, Van Ark I, Savelkoul HF, Cruikshank WW, Nijkamp FP and Van Oosterhout $A]$ V $\beta 8+T$ lymphocytes are essential in the regulation of airway hyperresponsiveness and bronchoalveolar eosinophilia but not in allergen-specific IgE in a murine model of allergic asthma. Clin Exp Allergy 1998, 28: I57|-I580

19. Irvin CG, Tu YP, Sheller JR and Funk CD 5-Lipoxygenase products are necessary for ovalbumin-induced airway responsiveness in mice. Am J Physiol 1997, 272:LI 053-LI058

20. Maeda $Y$, Musoh K, Shichijo M, Tanaka $H$ and Nagai $H$ Interferon- $\beta$ prevents antigen-induced bronchial inflammation and airway hyperreactivity in mice. Pharmacology 1997, 55:32-43

21. Kips JC, Brusselle GJ, Joos GF, Peleman RA, Tavernier JH, Devos RR and Pauwels RA Interleukin- $\mathbf{2}$ inhibits antigen-induced airway hyperresponsiveness in mice. Am J Respir Crit Care Med 1996, 153:535-539

22. Schwarze J, Hamelmann E, Cieslewicz G, Tomkinson A, Joetham A, Bradley $K$ and Gelfand EW Local treatment with IL- 12 is an effective inhibitor of airway hyperresponsiveness and lung eosinophilia after airway challenge in sensitized mice. J Allergy Clin Immunol 1998, 102:86-93

23. Leckie MJ, ten Brinke A, Khan J, Diamant Z, O'Connor BJ, Walls CM, Mathur AK, Cowley HC, Chung KF, Djukanovic R, Hansel TT, Holgate ST, Sterk PJ and Barnes PJ Effects of an interleukin-5 blocking monoclonal antibody on eosinophils, airway hyperresponsiveness, and the late asthmatic response. Lancet 2000 356:2। 44-2| 48

24. Nagai $H$, Yamaguchi $S$, Maeda $Y$ and Tanaka $H$ Role of mast cells, eosinophils and IL- 5 in the development of airway hyperresponsiveness in sensitized mice. Clin Exp Allergy 1996, 26:642-647

25. Kobayashi T, Miura T, Haba T, Sato M, Serizawa I, Nagai H and Ishizaka $K$ An essential role of mast cells in the development of airway hyperresponsiveness in a murine asthma model. J Immunol 2000, 164:3855-386

26. Hessel EM, Van Oosterhout AJ, Van Ark I, Van Esch B, Hofman G, Van Loveren H, Savelkoul HF and Nijkamp FP Development of airway hyperresponsiveness is dependent on interferon-gamma and independent of eosinophil infiltration. Am J Respir Cell Mol Biol 1997, 16:325-334

27. Coyle AJ, Kohler G, Tsuyuki S, Brombacher F and Kopf M Eosinophils are not required to induce airway hyperresponsiveness after nematode infection. Eur J Immunol I998, 28:2640-2647

28. Hessel EM, Cruikshank WW, Van Ark I, De Bie J], Van Esch B, Hofman G, Nijkamp FP, Center DM and Van Oosterhout AJ Involvement of IL-16 in the induction of airway hyperresponsiveness and up-regulation of IgE in a murine model of allergic asthma. J Immunol 1998, 160:2998-3005

29. Makela MJ, Kanehiro A, Borish L, Dakhama A, Loader J, Joetham A, Xing Z, Jordana M, Larsen GL and Gelfand EW IL- 10 is necessary for the expression of airway hyperresponsiveness but not pulmonary inflammation after allergic sensitization. Proc Nat Acad Sci USA 2000, 97:6007-60I 2

30. Tournoy KG, Kips JC, Schou C and Pauwels RA Airway eosinophilia is not a requirement for allergen-induced airway hyperresponsiveness. Clin Exp Allergy 2000, 30:79-85

31. Crimi E, Spanevello A, Neri M, Ind PW, Rossi GA and Brusasco V Dissociation between airway inflammation and airway hyperresponsiveness in allergic asthma. Am J Respir Crit Care Med 1998, 157:4-9
Publish with BioMed Central and every scientist can read your work free of charge

"BioMed Central will be the most significant development for disseminating the results of biomedical research in our lifetime. "

Sir Paul Nurse, Cancer Research UK

Your research papers will be:

- available free of charge to the entire biomedical community

- peer reviewed and published immediately upon acceptance

- cited in PubMed and archived on PubMed Central

- yours - you keep the copyright
BioMedcentral 